JAMP: Jurnal Adminitrasi dan Manajemen Pendidikan

Volume 1 Nomor 4 Desember 2018, Hal : 448-453

Tersedia Online di http://journal2.um.ac.id/index.php/jamp/

ISSN 2615-8574 (online)

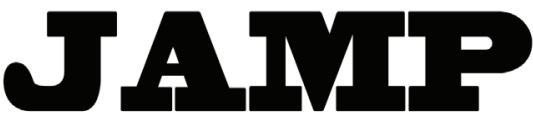

JURNAL ADMINISTRASI DAN MANAJEMEN PENDIDIKAN

\title{
MANAJEMEN LAYANAN KHUSUS DHAMYSOGA CHARACTER CAMP (DCC) SEBAGAI PEMBENTUK KARAKTER PESERTA DIDIK
}

\author{
Fauzi Firmansyah Putra \\ Mustiningsih \\ Raden Bambang Sumarsono \\ fauziputt@gmail.com
}

Universitas Negeri Malang, Jl. Semarang 5 Malang 65145

\begin{abstract}
Abstrak: Penelitian ini bertujuan untuk mendeskripsikan (1) perencanaan DCC, (2) pengorganisasian DCC, (3) pelaksanaan DCC dalam mengimplementasikan 5 nilai penguatan pendidikan karakter, (4) monitoring, evaluasi, dan dampak pelaksanaan DCC, dan (5) faktor pendukung, penghambat, dan solusi DCC. Penelitian ini menggunakan pendekatan kualitatif, dengan rancangan penelitian studi kasus. Hasil penelitian ini mengungkapkan (1) perencanaan DCC, (2) pengorganisasian DCC, (3) pelaksanaan DCC dalam mengimplementasikan 5 nilai penguatan pendidikan karakter, (4) monitoring, evaluasi, dan dampak pelaksanaan DCC, dan (5) faktor pendukung, penghambat, dan solusi DCC.
\end{abstract}

Kata Kunci: DCC, Manajemen, Karakter

\begin{abstract}
This study aims to describe (1) DCC planning, (2) the organization of DCC, (3) the implementation of DCC in implementing the 5 values of strengthening character education, (4) monitoring, evaluation, and impact of DCC implementation, and (5) supporting factors , inhibitors, and DCC solutions. This study uses a qualitative approach, with a case study research design. The results of this study revealed (1) DCC planning, (2) organization of DCC, (3) the implementation of DCC in implementing the 5 values of strengthening character education, (4) monitoring, evaluation, and impact of DCC implementation, and (5) supporting factors, inhibitors, and DCC solution.
\end{abstract}

Keywords: DCC, Management, Character

Krisis karakter seakan telah menjadi problema yang sedang dihadapi bangsa Indonesia pada era globalisasi, hal ini ditunjukkan dengan masalah dekadensi moral. Dekadensi moral dalam berbagai bidang kehidupan sedang mewabah dan banyak dipertontonkan oleh berbagai media, baik dalam bidang sosial, hukum, politik dan pemerintahan maupun dalam bidang budaya, seperti tawuran, kasus korupsi, kriminalitas, dan lain-lain yang tidak mencermin budaya dan perilaku asli bangsa Indonesia yang dikenal dengan keramahtamahan, santun, dan mempunyai karakter yang mulia. Rahmadi (2017), mengemukakan pada zaman sekarang perhatian generasi muda hanya berpusat pada pembangunan ekonomi dengan orientasi ke fisik, tak mengherankan apabila di kalangan anak muda tumbuh sifat materialisme, praktik korupsi, kolusi, dan nepotisme (KKN).

Pendidikan sangat diperlukan guna membangun karakter bangsa, baik pendidikan formal, informal maupun non formal. Sekolah merupakan salah satu lembaga pendidikan yang dapat digunakan untuk meningkatkan kualitas sumber daya manusia dalam pembangunan suatu bangsa melalui pembelajaran yang kontinyu. keberhasilan sekolah tidak hanya diukur dari tercapainya target akademis peserta didik, 
tetapi lebih pada proses pembelajaran sehingga mampu memberikan perubahan sikap serta perilaku peserta didik. Sesuai dengan fungsi dan tujuan pendidikan yang tercantum dalam Undang-Undang Nomor 20 Tahun 2003 tentang Sistem Pendidikan Nasional pada Pasal 3, sebagai berikut. Pendidikan nasional berfungsi mengembangkan kemampuan dan membentuk watak serta peradaban bangsa yang bermartabat dalam rangka mencerdaskan kehidupan bangsa, bertujuan untuk berkembangnya potensi peserta didik agar menjadi manusia yang beriman dan bertaqwa kepada Tuhan Yang Maha Esa, berakhlak mulia, sehat, berilmu, cakap, kreatif, mandiri, dan menjadi warga negara yang demokratis serta bertanggung jawab.

Penyelenggaraan sekolah perlu didukung dengan ketersediaan layanan yang layak serta memadai baik kuantitas maupun kualitasnya. Mengingat penyelenggaraan sekolah terus berubah dan berkembang, maka sekolah perlu mengupayakan layanan-layanan demi tercapainya tujuan pendidikan nasional. SMA Negeri 5 Malang melakukan upaya layanan dalam hal membentuk dan membina karakter peserta didiknya sesuai dengan fungsi dan tujuan pendidikan yang dinamakan Dhamysoga Character Camp (DCC).

\section{METODE}

Penelitian ini menggunakan pendekatan kualitatif karena sesuai dengan tema yang dipilih, yaitu cenderung menggali informasi, sehingga peneliti dapat mendeskripsikan fenomena yang terjadi secara menyeluruh dan mendalam. Menurut Moleong (dalam Ulfatin, 2015:24) penelitian kualitatif merupakan penelitian yang bertujuan untuk memahami peristiwa yang dialami oleh subjek penelitian contohnya perilaku, persepsi, motivasi, tindakan, dan lain-lain secara holistik, dan dengan cara deskripsi dalam bentuk narasi, pada suatu konteks dengan memanfaatkan berbagai metode ilmiah.

Penelitian ini menggunakan jenis penelitian studi kasus. Sukmadinata (2013) menyatakan bahwa penelitian kualitatif yang menggunakan studi kasus berarti penelitian difokuskan pada satu fenomena saja yang dipilih dan ingin dipahami secara mendalam, dengan mengabaikan fenomena-fenomena lainnya. Fenomena yang diteliti dilakukan penggalian secara mendalam dan menyeluruh dalam rangka menunjukkan adanya sesuatu yang khas untuk dapat dipelajari dari fenomena tersebut. Proses pengumpulan data menggunakan teknik wawancara, observasi, serta dokumentasi. Analisis data adalah proses penyusunan data secara sistematis yang diperoleh dari hasil pengumpulan data di lapangan, kemudian data-data tersebut direduksi, dirangkum, dan disesuaikan dengan fokus penelitian. Kemudian dilakukan verifikasi data dengan membuat kesimpulan berdasarkan data yang direduksi. Terakhir pengecekan keabsahan data menggunakan triangulasi sumber data serta metode/teknik.

\section{HASIL}

\section{Perencanaan DCC}

DCC merupakan program tahunan sekolah yang perencanaannya dilakukan pada awal tahun dan setelah sertijab OSIS dan MPK masa jabatan yang baru. Perencanaan DCC masuk dalam RKAS dimana program/kegiatan serta rinciannya sudah ada di dalam RKAS. Terdapat dana awal tahun merupakan uang yang dibayarkan oleh setiap peserta didik baru yang diterima di SMAN 5 Malang untuk beberapa kegiatan besar salah satunya DCC. Dilakukan berbagai berbagai tahap untuk mencapai kesepakatan, yaitu rapat awal, rapat forum, rapat lanjutan, rapat akbar sampai rapat pembubaran yang melibatkan para wakil kepala, pembina sekbid, guru PA, serta kepala sekolah. Tujuan yang ingin dicapai oleh SMAN 5 Malang ada dua, yaitu secara internal dan eksternal. Tujuan internal yaitu mencapai tujuan, fungsi, dan nilai pendidikan karakter sesuai amanat pemerintah tentang pendidikan karakter dan pengimplementasian nilai-nilai kepramukaan. Tujuan eksternal adalah membantu masyarakat desa yang dijadikan tempat berlangsungnya DCC. 


\section{Pengorganisasian DCC}

Pengorganisasian DCC dilakukan atas dasar bimbingan kepala sekolah kepada wakil kepala bidang kesiswaan yang kemudian berkoordinasi dengan wakil kepala bidang lain untuk membentuk panitia, membentuk struktur kepanitian, dan pembagian tugas (job desc).

\section{Pelaksanaan DCC}

DCC dilaksanakan selama tiga hari dua malam dengan Live in (tinggal di rumah penduduk). Setiap kegiatan peserta didik dibagi menjadi kelompok-kelompok, tujuannya agar mereka mampu menunjukkan 5 nilai utama karakter yaitu religius, nasionalis, mandiri, gotong royong, serta integritas, berikut diuraikan secara singkat hasil observasi pada kegiatan yang menunjukkan 5 nilai utama penguatan pendidikan karakter sebagai berikut. (1) Religius, karakter religius yang ditunjukkan oleh peserta didik dapat dilihat pada saat kegiatan Ishoma, terlebih waktu ibadah solat jum'at. Peserta didik yang non muslim beribadah sesuai dengan kepercayaannya masing-masing. (2) Nasionalis, karakter nasionalis yang ditunjukkan peserta didik dapat dilihat pada saat peserta didik memakai baju batik serta pada saat kegiatan inagurasi, dimana dalam kegiatan inagurasi tersebut anak SD dari desa sanankerto menampilkan tarian remo. Sikap mengapresiasi budaya bangsa sendiri sera memberi penghargaan kepada bangsa tampak pada saat kegiatan inagurasi berlangsung. (3) Mandiri, karakter mandiri yang ditunjukkan peserta didik dapat dilihat ketika peserta didik jelajah desa serta berada di rumah inang, yaitu ketika mereka menyiapkan perlengkapan pribadinya sendiri maupun kelompok. (4) Gotong royong, karakter gotong royong yang tunjukkan peserta didik dapat dilihat pada saat kegiatan abdi inang, yaitu ketika peserta didik membantu pekerjaan inang seperti membuat telor asin dan sapu lidi untuk dijual serta bersih desa. (5) Integritas, karakter integritas yang tunjukkan peserta didik dapat dilihat pada saat panitia menjalankan tugasnya dengan rasa tanggung jawab, dapat dipercaya dalam perkataan dan tindakan.

Pelaksanaan DCC terdapat LKS (lembar kerja siswa) yang mana dalam form LKS peserta didik harus menguraikan kegiatan yang dilakukan, LKS juga bermanfaat sebagai penilaian yaitu penilaian sikap yang diberikan oleh guru.

\section{Monitoring, Evaluasi, dan dampak DCC}

Monitoring yang dilakukan yaitu melalui pembimbing akademik (PA) dan dua orang sahabat kelas. Terdapat 31 kelas di SMAN 5 Malang, dimana 31 kelas tersebut didampingi oleh pembimbing akademik (PA) dan didampingi oleh dua siswa dari kepanitiaan yang dinamakan sahabat kelas, sahabat kelas bertugas memantau peserta DCC pada saat kegiatan. Monitoring oleh kepala sekolah yaitu berkoordinasi dengan PA. Evaluasi selalu dilakukan oleh kepala sekolah setiap DCC berakhir yang diadakan pada minggu berikutnya. Peserta didik dikumpulkan dari setiap sie dan diajak berdiskusi yang mana setiap sie sudah menyiapkan laporan dan dihimpun oleh sekretaris DCC kemudian disampaikan pada rapat pembubaran DCC. Dampak yang dirasakan oleh peserta didik yaitu hidup mandiri, gotong royong, tanggung jawab, bersosialisasi, belajar arti kehidupan, dan mempunyai sikap peduli sesama.

\section{Faktor Pendukung, Penghambat, dan Solusi DCC}

Dukungan yang didapat oleh SMAN 5 Malang dalam melaksanakan DCC yaitu dari donatur, alumni yang berprofesi sebagai dokter umum, dokter gigi, dan dokter mata, organisasi seperti Al-Kahfi yang membantu dan mendukung baik materil dan emosional. Kerja sama juga dilakukan dengan pihak kelurahan, kecamatan desa, orangtua peserta didik, kepolisian, TNI AD, dan polresta. Hambatan atau masalah terjadi pada saat DCC berlangsung, akan tetapi solusi tercipta dan menjawab hambatan tersebut tepat pada waktunya. 


\section{PEMBAHASAN}

\section{Perencanaan DCC}

Kegiatan perencanaan merupakan tahap awal dari manajemen. perencanaan DCC yang dilakukan oleh SMAN 5 Malang yaitu meliputi penyusunan pada awal tahun ajaran baru yang disusun didalam RKAS, selanjutnya dalam mencapai keputusan dilakukan melalui berbagai tahap rapat. Perencanaan DCC tersebut juga sejalan dengan pendapat (Kurniadin \& Machali, 2012: 117) yakni perencanaan yaitu proses kegiatan yang rasional dan sistemik dalam menetapkan keputusan, kegiatan atau langkahlangkah yang akan dilaksanakan dikemudian hari dalam rangka untuk mencapai tujuan secara efektif dan efisien, serta pendapat (Zulkarnain, 2016: 53) yaitu perencanaan merupakan analisis kebutuhan dan penyusunan program layanan khusus.

\section{Pengorganisasian DCC}

Pengorganisasian dimaksudkan agar tujuan dari sebuah perencanaan dapat terlaksana, diwujudkan dalam bentuk struktur kepanitiaan dan jabatan. Pada setiap jabatan ada tugas, tanggungjawab, dan wewenang. Berdasarkan hasil dapat diketahui bahwa pengorganisasian DCC meliputi membentuk kepanitiaan DCC, menetapkan struktur kepanitian, serta pembagian tugas/jobdesc. Pengorganisasian DCC tersebut selaras dengan pendapat (Zulkarnain, 2016: 53) pengorganisasian berupa pembagian tugas untuk melaksanakan program layanan khusus, serta pendapat (Kurniadin \& Machali, 2012:241) pengorganisasian pendidikan bertujuan untuk mencapai tujuan pendidikan yang diinginkan

\section{Pelaksanaan DCC}

Terdapat 5 nilai utama karakter yang berusaha dikembangkan oleh SMAN 5 Malang melalui DCC sebagai prioritas gerakan PPK, yaitu (1) Religius, peserta didik melaksanakan ajaran agama, menghargai perbedaan agama, hidup rukun dan damai dengan pemeluk agama lain; (2) Nasionalis, peserta didik menunjukkan kepedulian terhadap bahasa, lingkungan fisik, sosial, budaya, apresiasi budaya bangsa sendiri, menjaga lingkungan, taat hukum, disiplin, menghormati keragaman budaya, suku, dan agama; (3) mandiri, peserta didik menunjukan sikap dan perilaku tidak bergantung pada orang lain serta kerja keras; (4) gotong royong, peserta didik mencerminkan tindakan menghargai semangat kerja sama dan bahu membahu menyelesaikan persoalan bersama, menjalin komunikasi dan persahabatan, memberi bantuan/pertolongan pada orang-orang yang membutuhkan; dan (5) integritas, peserta didik menunjukan sikap tanggung jawab sebagai warga negara, aktif terlibat dalam kehidupan sosial, melalui konsistensi tindakan dan perkataan yang berdasarkan kebenaran.

Pengimplementasian 5 nilai karakter tersebut dilakukan selama kegiatan DCC dengan sistem live in yaitu tinggal dirumah penduduk, artinya selama DCC berlangsung kegiatan yang dilakukan berpusat pada desa yang disinggahi, pelaksanaan dan tata tertib diatur dalam petunjuk pelaksanaan dan petunjuk teknis DCC. Pelaksanaan DCC tersebut sejalan dengan pendapat (Kurniadin \& Machali, 2012: 287) penggerakan adalah tindakan untuk memulai, memprakasai, memotivasi, mengarahkan, dan mempengaruhi para pegawai mengerjakan tugas-tugas untuk mencapai tujuan organisasi serta pendapat (Zulkarnain, 2016: 53) penggerakan berupa pengaturan dalam pelaksanaan layanan khusus.

Pelaksanaan DCC oleh SMAN 5 Malang telah dikemas sebagai kegiatan yang partisipasi, aktif, kreatif, dan menyenangkan bagi peserta didik. Rohiat (2012: 28), mengemukakan bahwa manajemen layanan khusus untuk mendukung keberhasilan program belajar mengajar keberhasilan program belajar mengajar membutuhkan fasilitas lain untuk mencapai keberhasilan belajar tersebut diantaranya ditunjukkan dengan pusat sumber belajar. Pendidikan karakter juga merupakan pusat sumber belajar.

Januswenski \& Molenda (2008: 231) mengemukakan bahwa sumber belajar adalah "The term resource is understood to include the tools, materials, devices, settings, and people that leaners interact with to facilitate learning and improve performance". Pendapat ini dipahami bahwa sumber belajar (resources) terdiri dari alat-alat, bahan, perangkat, pengaturan, dan orang-orang yang berinteraksi dengan peserta didik untuk memfasilitasi belajar dan meningkatkan kinerja. Direktorat Pembinaan SMA (2010: 7), pusat sumber belajar SMA (PSB-SMA) merupakan sistem pengelolaan yang teroganisasi 
untuk menyusun, mengembangkan, dan menyediakan sumber belajar dalam mendukung proses pembelajaran dengan memanfaatkan teknologi informasi dan komunikasi sebagai media informasi dan komunikasi, wahana belajar, dan media untuk kinerja. Berdasarkan pendapat di atas dapat disimpulkan bahwa DCC merupakan pusat sumber belajar yang di dalamnya terdapat pesan, bahan, alat, kondisi lingkungan, maupun orang-orang yang berinteraksi dengan peserta didik dan dapat memberikan peserta didik sejumlah informasi, pengetahuan, pengalaman, dan keterampilan serta mampu mengamalkan 5 nilai utama penguatan pendidikan karakter sebagai tujuan DCC.

\section{Monitoring, Evaluasi, dan Dampak DCC}

Monitoring/pengawasan merupakan tindakan untuk menilai sejauh mana keberhasilan program yang dilaksanakan. Monitoring/pengawasan merupakan proses dalam rangka menetapkan ukuran kinerja dan pengambilan tindakan yang dapat mendukung pencapaian hasil yang diharapkan sesuai dengan kinerja yang telah ditetapkan. Berdasarkan hasil dapat di ketahui pengawasan yang dilakukan dalam DCC dilakukan oleh PA dibantu dengan sahabat kelas, kepala sekolah juga ikut mengawasi dengan cara berkoordinasi dengan PA, serta LKS guna mengontrol kegiatan apa saja yang telah dilakukan oleh tiap peserta didik yang akan dijadikan dalam penilaian sikap.

Evaluasi juga selalu dilakukan oleh kepala sekolah setiap DCC berakhir. Kegiatan monitoring/ pengawasan serta evaluasi ini sejalan dengan pendapat (Kurniadin \& Machali, 2012: 241) pengawasan adalah suatu kegiatan untuk mendapatkan kepastian tentang pelaksanaan program atau kegiatan yang sedang atau telah dilakukan sesuai dengan rencana yang telah ditentukan, serta pendapat (Zulkarnain, 2016: 53) pengawasan berupa pemantauan dan penilaian layanan khusus di sekolah. Dampak yang dirasakan oleh peserta didik yaitu hidup mandiri, gotong royong, tanggung jawab, bersosialisasi, belajar arti kehidupan, dan mempunyai sikap peduli sesama yang pada dasarnya masuk dalam 5 nilai utama PPK yaitu religius, mandiri, nasionalis, integritas, dan gotong royong.

\section{Faktor Pendukung, Penghambat, dan Solusi DCC}

Dukungan yang didapatkan sekolah dalam pelaksanaan DCC mendapatkan respon yang positif yaitu dukungan moril, dukungan ide kreatif, dan dukungan materiil didapatkan dari donatur, alumni SMAN 5 Malang yang berprofesi sebagai dokter umum, dokter gigi, dan dokter mata serta organisasi seperti Al-Kahfi yang membantu secara materil dan emosional yaitu dalam bidang keagamaan.

Kerjasama juga dilakukan oleh SMAN 5 Malang dengan pihak eksternal yaitu bekerja sama dengan kelurahan, kecamatan desa, kepolisian, TNI AD, dan polresta. Hambatan atau masalah terjadi pada saat DCC berlangsung, akan tetapi solusi tercipta dan menjawab hambatan tersebut tepat pada waktunya.

\section{KESIMPULAN}

Perencanaan DCC dilakukan pada awal tahun masuk dalam RKAS dan di dalam mencapai keputusan dilakukan melalui berbagai tahap rapat. pengorganisasian DCC meliputi membentuk sebuah kepanitiaan DCC, struktur DCC, serta pembagian tugas/jobdesc.

Pelaksanaan DCC yaitu dengan sistem live in (tinggal dirumah penduduk), artinya selama DCC berlangsung kegiatan yang dilakukan berpusat pada desa yang disinggahi hal ini membuat peserta didik dapat mengimplementasikan 5 nilai utama PPK yaitu religius, nasionalis, mandiri, gotong royong, dan integritas melalui serangkaian kegiatan DCC, serta pelaksanaan dan tata tertib diatur dalam juklak dan juknis serta susunan kegiatan DCC.

Monitoring dilakukan oleh PA dibantu dengan sahabat kelas, untuk mengawasi peserta didik dalam melakukan kegiatan selama DCC berlangsung, kepala sekolah juga ikut mengawasi dengan cara berkoordinasi dengan PA, serta LKS yang diberikan guna mengontrol kegiatan apa saja yang telah dilakukan oleh tiap peserta didik dan dinilai dalam penilaian sikap. Evaluasi juga selalu dilakukan oleh kepala sekolah setiap DCC berakhir yang diadakan pada minggu berikutnya. 
Faktor pendukung, penghambat, dan solusi didapatkan dari donatur, alumni SMAN 5 Malang yang berprofesi sebagai dokter umum, dokter gigi, dan dokter mata serta organisasi seperti Al-Kahfi yang membantu secara materil dan emosional yaitu dalam bidang keagamaan. Kerjasama juga dilakukan oleh SMAN 5 Malang dengan pihak eksternal yaitu bekerja sama dengan kelurahan, kecamatan desa, orangtua peserta didik, kepolisian, TNI AD, serta foreder dari polresta. Hambatan atau masalah terjadi pada saat DCC berlangsung, akan tetapi solusi tercipta dan menjawab hambatan tersebut tepat pada waktunya.

\section{DAFTAR RUJUKAN}

Departemen Pendidikan Nasional. 2010. Konsep Pusat Sumber Belajar SMA. Jakarta: Dirjen Dikdasmen Direktorat Pembinaan SMA.

Januswenski, A \& Molenda, M. 2008. Education Technology a Definition with Commetary. NewYork: Lawrence Erlbraum Associates Taylor \& Francis Group.

Kurniadin, D \& Machali, I. 2012. Manajemen Pendidikan: Konsep \& Prinsip Pengelolaan Pendidikan. Jogjakarta: Ar Ruzz Media.

Rahmadi. 2017. Reaktualisasi Pendidikan Karakter Bagi Generasi Muda, Dari https://kalsel.kemenag.go.id/.../ reaktualisasi-pendidikan-karakter-bagi-generasi-muda

Rohiat. 2012. Manajemen Sekolah:Teori Dasar Dan Praktik Dilengkapi Dengan Contoh Strategis Dan Rencana Operasional. Bandung: Refika Aditama.

Sukmadinata, N. S. 2013. Metode Penelitian Pendidikan. Bandung: PT Remaja Rosdakarya.

Ulfatin, N. 2015. Metode Penelitian Kualitatif di Bidang Pendidikan: Teori dan Aplikasinya. Malang: Media Nusa Creative.

Undang-Undang Republik Indonesia Nomor 20 Tahun 2003 tentang Sistem Pendidikan Nasional. 2006. Bandung: Citra Umbara.

Zulkarnain, W. 2016. Layanan Khusus Peserta Didik Sebagai Penguat Manajemen Pendidikan. Dari ap.fip.um.ac. id/wp-content/uploads/.../4-Wildan-Zulkarnain.pdf 